\title{
Renal ACE2 expression and activity is unaltered during established hypertension in adult SHRSP and TGR(mREN2)27
}

\author{
Jelena Kamilic ${ }^{1,7}$, Inge Hamming ${ }^{1,7}$, Reinhold Kreutz ${ }^{2}$, Juliane Bolbrinker ${ }^{2}$, Wolf-Eberhard Siems ${ }^{3}$, \\ Ibrahim Nassar ${ }^{2}$, Judith C Sluimer ${ }^{4}$, Thomas Walther ${ }^{5}$, Gerjan J Navis ${ }^{6}$ and Harry van Goor ${ }^{1}$
}

Differential renal expression of a homolog of the angiotensin-converting enzyme (ACE), that is, ACE2, has been implicated as a genetic basis of polygenetic hypertension in the stroke-prone spontaneously hypertensive rat model. However, data on the role of ACE2 in hypertension are still inconclusive. Therefore, we analyzed kidney ACE2 mRNA, ACE2 protein and ACE2 enzyme activities in the adult polygenetic stroke-prone spontaneously hypertensive rat (SHRSP) and the monogenetic TGR(mREN2)27 rat models, in comparison with their normotensive reference strains, Wistar-Kyoto (WKY) and Spraque-Dawley (SD) rats, respectively. Kidney ACE2 mRNA was studied using quantitative real-time reverse transcriptase-PCR (RT-PCR) in cortex and medulla, whereas protein expression was scored semiquantitatively in detail in different renal structures using immunohistochemistry. Furthermore, total renal tissue ACE2 activity was measured using a fluorimetric assay that was specified by the ACE2 inhibitor DX600. In SHRSP and homozygous TGR(mREN2)27 rats with established hypertension, kidney ACE2 mRNA, protein and tissue ACE2 activities were not different from their respective WKY and SD reference strain, respectively. In addition, when we looked at renal localization, we found ACE2 protein to be predominantly present in glomeruli and endothelium with weak staining in distal and negative staining in proximal tubuli. Thus, our data challenge previous work that implicates ACE2 as a candidate gene for hypertension in SHRSP by reporting a significant reduction of ACE2 in the kidneys of SHRSP. Taken together, renal ACE2 is not altered in the SHRSP and TGR(mREN2)27 genetic rat models with established hypertension.

Hypertension Research (2010) 33, 123-128; doi:10.1038/hr.2009.191; published online 20 November 2009

Keywords: ACE2; kidney; rat; stroke-prone SHR

\section{INTRODUCTION}

Angiotensin-converting enzyme (ACE), a key enzyme of the reninangiotensin system (RAAS), has a crucial role in renal (patho) physiology. It converts Angiotensin (Ang) I into AngII, a potent vasoconstrictive, pro-inflammatory and pro-fibrotic peptide. The only known homolog of ACE, the angiotensin-converting enzyme 2 (ACE2) has been identified in humans and rodents. ${ }^{1}$ ACE2 functions as a zinc metallopeptidase with carboxypeptidase activity. ACE2 hydrolyzes AngI to generate Ang(1-9), a peptide with unknown effects on the vascular bed. In addition, it catalyzes hydrolysis of AngII to Ang (1-7), a potent vasodilator and antiproliferative peptide. The efficacy of ACE2 for the conversion of AngI to Ang (1-9) in humans is 400fold lower than for the generation of Ang (1-7) from AngII. ${ }^{2,3}$ ACE2 may act as a negative regulator of ACE and the RAAS by limiting the production or antagonizing the vasoconstrictive effect of AngII and facilitating the formation of Ang (1-7).

It was initially hypothesized that disruption of the delicate balance between ACE and ACE2 would result in abnormal blood pressure control. ${ }^{4}$ In that line of thinking, increased ACE2 activity might protect against increases in blood pressure and ACE2 deficiency might lead to hypertension. In early animal studies, a potential role of ACE2 for blood pressure regulation and the pathogenesis of hypertension was supported by the fact that ACE2 maps to the $\mathrm{X}$ chromosome and shows colocalization with blood pressure quantitative trait loci $(\mathrm{QTLs})^{5}$ that have been identified in polygenetic rat models of hypertension, including the stroke-prone spontaneously hypertensive rat (SHRSP) ${ }^{6}$ and the salt-sensitive Sabra hypertensive $(\mathrm{SBH} / \mathrm{y})$ rat model of genetic hypertension. ${ }^{7}$ In addition, it was

${ }^{1}$ Department of Pathology and Medical Biology, University Medical Center Groningen, University of Groningen, Groningen, The Netherlands; ${ }^{2}$ Department of Clinical Pharmacology, Charité-University Medicine Berlin, Campus Benjamin Franklin (CBF), Berlin, Germany; ${ }^{3}$ Biochemical Neurobiology, Leibniz-Institut für Molekulare Pharmakologie (FMP), Berlin, Germany; ${ }^{4}$ Department of Pathology, Cardiovascular Research Institute Maastricht (CARIM), University of Maastricht, Maastricht, The Netherlands; ${ }^{5}$ Department of Cardiovascular Physiology, Hull York Medical School, The University of Hull, Hull, UK and ${ }^{6}$ Department of Nephrology, University Medical Center Groningen, University of Groningen, Groningen, The Netherlands

${ }^{7}$ These authors contributed equally to this work.

Correspondence: Dr J Kamilic, Department of Pathology and Medical Biology, University Medical Center Groningen, University of Groningen, PO Box 30.001 , Groningen 9700 RB, the Netherlands.

E-mail: j.kamilic@path.umcg.nl

Received 3 June 2009; revised 27 September 2009; accepted 14 October 2009; published online 20 November 2009 
reported that renal ACE2 expression was decreased in these hypertensive strains when compared with the normotensive reference strains. ${ }^{5}$ Moreover, stimulation of RAAS gene expression in SHR by all-trans retinoic acid (at-RA) for 3 weeks increased natively low kidney ACE2 mRNA, which was associated with a reduction in blood pressure. However, other data were at variance with a causal role for ACE2 in the pathogenesis of hypertension. In the above study, ACE2 protein levels in SHR were increased and almost reached the levels of the control rats, with blood pressure elevated in comparison with the controls, thus putting into question a straightforward association between renal ACE2 and blood pressure. ${ }^{8}$ In addition, in knockout mice lacking the ACE2 gene, blood pressure was normal or only modestly increased in comparison with their background strain, despite increased AngII plasma and tissue levels. ${ }^{5,9}$ These findings suggest that the role of ACE2 in blood pressure control is not a uniform phenomenon and is apparently context dependent. In humans, data so far do not support a role for ACE2 in the genetics of hypertension, given the absence of association between single-nucleotide polymorphisms in the ACE2 locus and essential hypertension. ${ }^{10}$

Thus, data on the role of ACE2 in blood pressure regulation and hypertension are still inconclusive. To address a possible role for renal ACE2 in established hypertension, we analyzed kidney ACE2 mRNA, ACE2 protein and ACE2 enzyme activities in two different genetic rat models of hypertension, namely the polygenetic SHRSP and the monogenetic TGR(mREN2)27 rat models in comparison with their normotensive reference strains, Wistar-Kyoto (WKY) and the SpraqueDawley (SD) rats, respectively.

\section{METHODS}

\section{Animals}

This study was conducted in accordance with the National Institutes of Health (NIH) guidelines for the care and use of laboratory animals. All animal experiments were approved by the animal research ethics committee of the University Medical Centre Groningen. SHRSP, WKY, TGR(mREN2)27 and SD rats were obtained from our own colony in Berlin. SHRSP and WKY strains are directly derived from the original colonies from Heidelberg that were used in the co-segregation analysis in which the first blood pressure QTL on rat chromosome X was identified. Moreover, SHRSP and WKY animals with established hypertension were studied at a similar age of 14 weeks compared with the $\mathrm{F}_{2}$ hybrids derived from SHRSP and WKY that were analyzed in the original linkage study. ${ }^{6}$

Homozygous TGR(mREN2)27 animals develop severe hypertension at an early age and were therefore studied at 8 weeks of age as reported. ${ }^{11}$ Rats were kept under conditions of regular $12 \mathrm{~h}$ diurnal cycles using an automated light switching device and climate-controlled conditions at a room temperature of $22^{\circ} \mathrm{C}$. The rats were fed a normal pelleted diet containing $0.2 \%$ sodium chloride $(\mathrm{NaCl})$ and had free access to food and water. Systolic blood pressure and urinary albumin excretion were determined as previously reported. ${ }^{12}$

Animals were killed under Ketamin $\mathrm{HCl}\left(87 \mathrm{mg} \mathrm{kg}^{-1}\right.$ body weight; Ketanest S, Pfizer, Karlsruhe, Germany) and Xylazine ( $13 \mathrm{mg} \mathrm{kg}^{-1}$ body weight; Rompun, Beyer, Leverkusen, Germany) anesthesia at 14 weeks of age. After induction of anesthesia, the abdomen was opened by a vertical incision. Blood was drawn from the abdominal aorta and through the same puncture saline was infused, allowing both kidneys to be perfused before excision. Using this procedure precludes contamination of renal tissue by blood or serum components and thus eliminates the possibility of serum ACE2 tissue contamination. The absence of blood is visually verified by the absence of erythrocytes in the lumen of renal blood vessels in Figure 2. Both kidneys were excised, and the left kidney was additionally dissected into cortex and medulla, and immediately frozen in liquid nitrogen and stored at $-80^{\circ} \mathrm{C}$.

\section{Real-time RT-PCR for ACE2}

To quantify mRNA expression of ACE2 in kidney, we used the real-time quantitative RT ('TaqMan') PCR. Appropriate primers and fluorogenic probes were designed with the PrimerExpress software (Applied Biosystems, Darmstadt, Germany). The ABI PRISM 7000 SDS instrument in conjunction with the ABI TaqMan Universal Master Mix (Applied Biosystems) was used to perform the assays. The reaction volume was $25 \mu \mathrm{l}$ with a final concentration of $900 \mathrm{~nm}$ for the primers and $200 \mathrm{~nm}$ for the probes. PCR conditions were used as recommended by the manufacturer. The primers were obtained from Proligo (Paris, France) with forward (F) and reverse (R) primer sequences F: 5'-GAGGA GAATGCCCAAAAGATGA-3' and R: 5'-GAAATTTTGGGCGATCTTGGA-3'. The fluorogenic probe was synthesized by TIB Molbiol (Berlin, Germany) (5'FAM-CTGCGGCCAAATGGTCTGCCTT-3' TAMRA). Relative quantitation was performed using the standard curve method. For each gene, a PCR fragment containing the sequence of the TaqMan system was generated. In all, seven serial 1:10 dilutions of this fragment served as a standard curve that was assayed together with the corresponding unknown samples on each plate. Every sample was measured in triplicate. To normalize our expression data, we used porphobilinogen deaminase (PBGD) as a housekeeping gene. ${ }^{11}$

\section{ACE2 immunohistochemistry}

Angiotensin-converting enzyme 2 immunohistochemistry was performed on frozen and paraffin kidney sections. Frozen slides were fixed in acetone for $10 \mathrm{~min}$. Paraffin sections were incubated overnight at $+80^{\circ} \mathrm{C}$ in Tris- $\mathrm{HCl}$ buffer ( $\mathrm{pH}$ 9). A polyclonal rabbit anti-ACE2 antiserum (a kind gift of the ACE2 antibody from Millennium Pharmaceuticals Inc., Cambridge, MA, USA $)^{13}$ diluted in phosphate-buffered saline (PBS) and supplemented with $1 \%$ bovine serum albumin, in a concentration of 1:750 for frozen and 1:500 (WKY) or 1:750 (TGR(mREN2)27, SD and SHRSP) for paraffin sections was incubated for $1 \mathrm{~h}$ at room temperature. Endogenous peroxidase was blocked for $30 \mathrm{~min}$ $\left(0.075 \%\right.$ hydrogen peroxide $\left(\mathrm{H}_{2} \mathrm{O}_{2}\right)$ in PBS, $\mathrm{pH}$ 7.4) for paraffin sections before and for frozen sections after primary $\mathrm{Ab}$ incubation. Antibody binding was detected using sequential incubations with peroxidase-labeled goat anti-rabbit and peroxidase-labeled rabbit anti-goat antibodies (GARPO/RAGPO Dako, Glostrup, Denmark). Normal rat serum (1\%) was added to the secondary antibodies to block a specific binding. Peroxidase activity was developed by using 3-amino-9-ethylcarbazole (AEC) for $10 \mathrm{~min}$ containing $0.03 \% \mathrm{H}_{2} \mathrm{O}_{2}$. Counterstaining was performed using Mayer's hematoxylin.

In all, three types of control tests were performed to determine the specificity of the antibody. First, control sections were incubated with anti-ACE2 antibody solutions, which were pre-incubated with the synthetic peptide to which the antibody was raised (peptide sequence: NTNITEENVQNMNNAGDKW aa51-69, Pepscan Systems BV, Lelystad, The Netherlands). Second, sections were incubated with unrelated rabbit polyclonal antibodies (anti-alpha1Inhibitor3 or anti-Nitrotyrosine) and third, the sections were incubated with PBS in the absence of the primary antibodies. These control sections did not reveal any staining.

\section{Analysis of structural changes}

The structures that were positive for ACE2 were analyzed and scored semiquantitatively in a blinded manner. The combined intensity and distribution of ACE2 immunostaining were determined on a scale of 0 to $2+$ ( 0 absent; $+/$ - very weak staining; + moderate staining; ++ strong staining) for different parts of the glomerulus (mesangium, endothelium, visceral epithelium and parietal epithelium), tubuli (proximal and distal tubuli, collecting ducts), vascular structures in the cortex (vascular smooth muscle cells, vascular endothelium, peritubular capillaries) and vascular structures in the medulla (vasa recta).

\section{ACE2 activity}

Angiotensin-converting enzyme 2 activity was measured according to the method by Vickers et al. ${ }^{3}$ Renal tissue was homogenized in assay buffer ( $50 \mathrm{~mm} 2$ morpholinoethanesulfonic acid, $300 \mathrm{~mm} \mathrm{NaCl}, 10 \mu \mathrm{M}$ zinc chloride $\left(\mathrm{ZnCl}_{2}\right), 0.01 \%$ Brij-35, $\mathrm{pH}$ 6.5). Protein concentration was determined using Roti-Quant (Carl Roth GmbH and Co. KG, Karlsruhe, Germany) according to the manufacturer's instruction. We used Mca-APK(Dnp) (Biosynthan GmbH, 
Berlin, Germany) that was dissolved in dimethyl sulfoxide (DMSO; $50 \mu \mathrm{M}$, final concentration) as the ACE2 substrate. The assay was performed in assay buffer and was started by adding $10 \mu \mathrm{l}$ of tissue homogenate. After $2 \mathrm{~h}$ of incubation at ambient temperature $\left(24^{\circ} \mathrm{C}\right)$, the reaction was suppressed by adding $100 \mu \mathrm{M}$ $o$-phenanthrolin (final concentration). Parallel control tests were performed in the presence of $1 \mu \mathrm{M}$ DX600 (R\&D Systems GmbH, Wiesbaden-Nordenstadt, Germany) (data not shown). ${ }^{14}$ After centrifugation $(10 \mathrm{~min}, 10000 \times g)$, the fluorescence was measured at $320 \mathrm{~nm}$ (excitation) and $405 \mathrm{~nm}$ (emission) using the Perkin-Elmer fluorescence reader Lambda 5 (Perkin-Elmer LAS GmbH, Rodgau, Germany). The molecular standardization was performed using Mca-AP (Biosynthan $\mathrm{GmbH}$ ) and calculated per mg protein. The functionality of the assay was proven by a standardized solution with defined, recombinant ACE2 activity (R\&D Systems GmbH).

\section{Statistics}

Data are presented as mean \pm s.d. The differences between the hypertensive strain and its normotensive control were analyzed using the Mann-Whitney $U$-test (SPSS 12.0; SPSS Inc., Chicago, IL, USA). Significant differences were obtained when $P<0.05$, and all $P$-values were calculated from two-tailed tests of statistical significance.

\section{RESULTS}

\section{Rat characteristics}

Table 1 summarizes the characteristics for the hypertensive and normotensive rat strains. Both SHRSP and TGR(mREN2)27 rats showed significantly higher blood pressure and lower body weights than their respective controls. Homozygous TGR(mREN2)27 rats already showed a significant increase in urinary albumin excretion at 8 weeks of age whereas SHRSP showed normal albumin excretion levels that were similar to the normotensive rat strains.

\section{ACE2 mRNA}

Angiotensin-converting enzyme $2 \mathrm{mRNA}$ levels were measured using quantitative RT-PCR in renal cortex and medulla. The results are presented in Figure 1. SHRSP rats had similar ACE2 mRNA levels compared with WKY in both cortex and medulla. ACE2 mRNA levels in TGR(mREN2)27 cortex were lower than in SD cortex, but this did not reach statistical significance. No differences in ACE2 mRNA levels were found between TGR(mREN2)27 and SD medulla.

\section{ACE2 immunohistochemistry}

The immunohistochemical staining pattern of renal ACE2 was uniform in all rat strains, whether normotensive or hypertensive. Moreover, the pattern of ACE2 staining was consistent between frozen and paraffin sections. In the glomeruli, moderate ACE2 expression was observed in parietal epithelial cells and abundant ACE2 expression in visceral epithelial cells, whereas the glomerular mesangial and endothelial cells were consistently negative for ACE2 (Figure 2 and Table 2). In vascular structures, ACE2 was abundantly expressed in vascular smooth muscle cells (VSMCs) and endothelial cells, with the exception of the endothelium of peritubular capillaries (Table 2). Remarkably, VSMCs of larger cortical radial (interlobular) arteries have less ACE2 expression than VSMCs of smaller preglomerular arterioles. This effect was most pronounced in SHRSP and WKY rats. Proximal tubuli did not reveal ACE2 expression whereas distal tubuli showed weak, predominantly intracellular ACE2 expression on the basal side of the cells. Collecting ducts were consistently negative for ACE2.

The extent of ACE2 protein expression was scored semiquantitatively for all the renal structures in cortex and medulla and the results are presented in Table 2. No differences in ACE2 expression were found between SHRSP and WKY rats and between TGR(mREN2)27 and $\mathrm{SD}$ rats (Figure 2).
Table 1 Rat characteristics

\begin{tabular}{lcccc}
\hline & $\begin{array}{c}\text { WKY } \\
(\mathrm{n}=9)\end{array}$ & $\begin{array}{c}\text { SHRSP } \\
(\mathrm{n}=8)\end{array}$ & $\begin{array}{c}\text { SD } \\
(\mathrm{n}=6)\end{array}$ & $\begin{array}{c}\text { TGR(mREN2)27 } \\
(\mathrm{n}=6)\end{array}$ \\
\hline Body weight (g) & $289 \pm 23$ & $260 \pm 18^{\mathrm{a}}$ & $279 \pm 28$ & $202 \pm 8^{\mathrm{a}}$ \\
SBP (mm Hg) & $124 \pm 9$ & $191 \pm 10^{\mathrm{a}}$ & $125 \pm 16$ & $197 \pm 38^{\mathrm{a}}$ \\
Urinary albumin & $0.55 \pm 0.23$ & $0.71 \pm 0.45$ & $0.30 \pm 0.21$ & $20.1 \pm 13.41^{\mathrm{a}}$ \\
excretion (mg day $\left.{ }^{-1}\right)$ & & & &
\end{tabular}

Abbreviations: ACE2, angiotensin-converting enzyme 2; SBP, systolic blood pressure; SD, Spraque-Dawley; SHRSP, stroke-prone spontaneously hypertensive; WKY, Wistar-Kyoto. ${ }^{a} P<0.05$ compared with the normotensive reference strain.
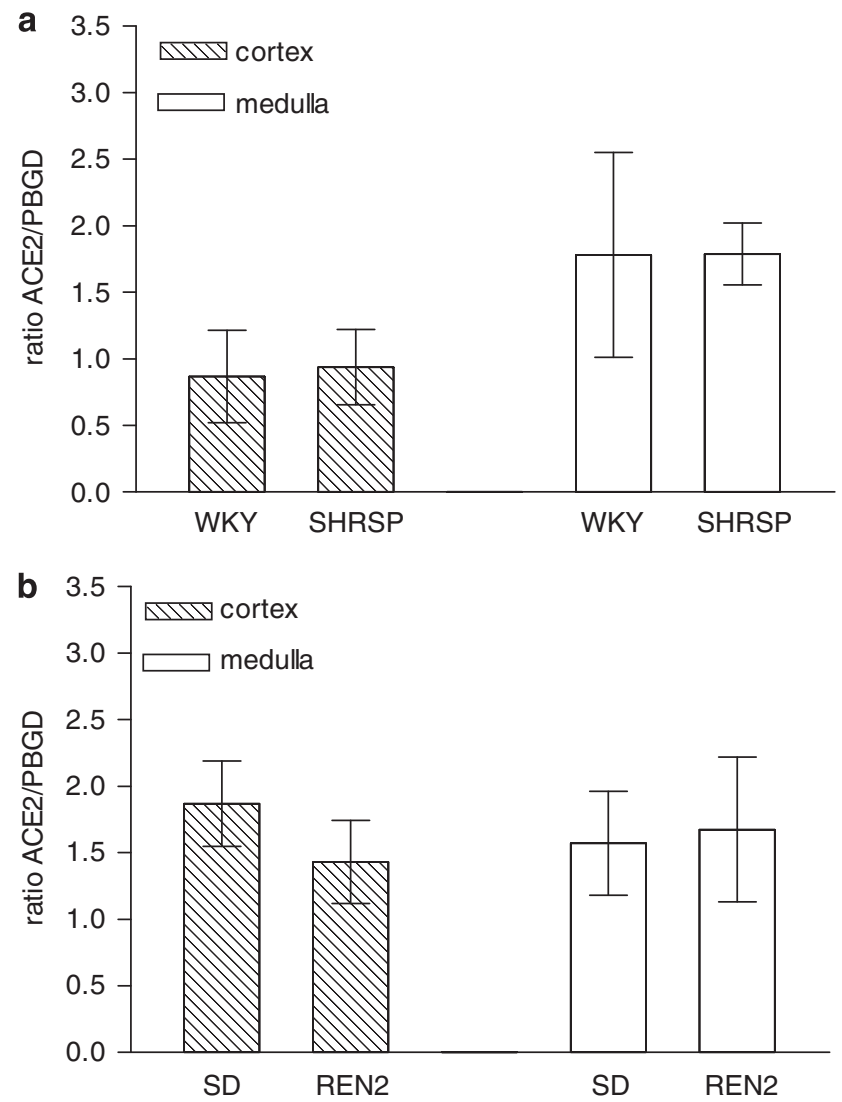

Figure 1 Angiotensin-converting enzyme 2 (ACE2) mRNA levels measured using quantitative reverse transcriptase-PCR (RT-PCR) in renal cortex and medulla. (a) No differences were found in renal cortical and medullar ACE2 between stroke-prone spontaneously hypertensive rats (SHRSP) and WistarKyoto (WKY) rats. (b) No differences were found in renal cortical and medullar ACE2 between TGR(mREN2)27 rats with renin-dependent hypertension and normotensive Spraque-Dawley (SD) rats.

\section{Tissue ACE2 activity}

In accordance with the renal mRNA and protein expression data, no differences were found in tissue ACE2 activity between the hypertensive strains and their normotensive reference strains (Table 3 ). Notably, ACE2 activity was higher in SD and REN2 rats when compared with WKY and SHRSP rat strains.

\section{DISCUSSION}

The major finding of our study is the absence of any differences in kidney ACE2 mRNA, ACE2 protein and ACE2 activity between the 
Frozen section

\section{WKY}
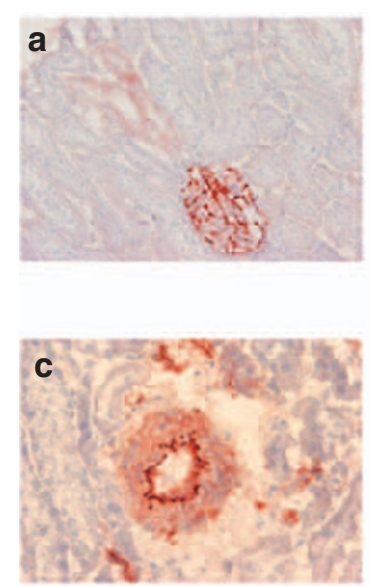

SHRSP
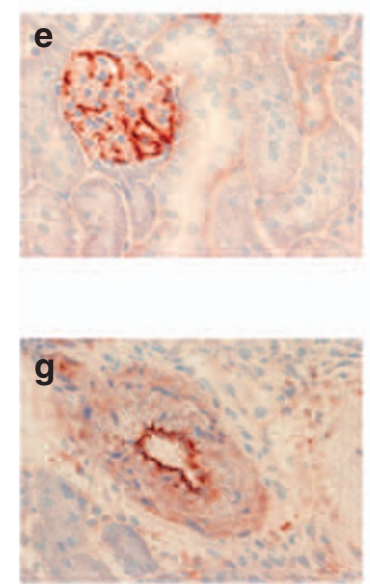

\section{Paraffin section}
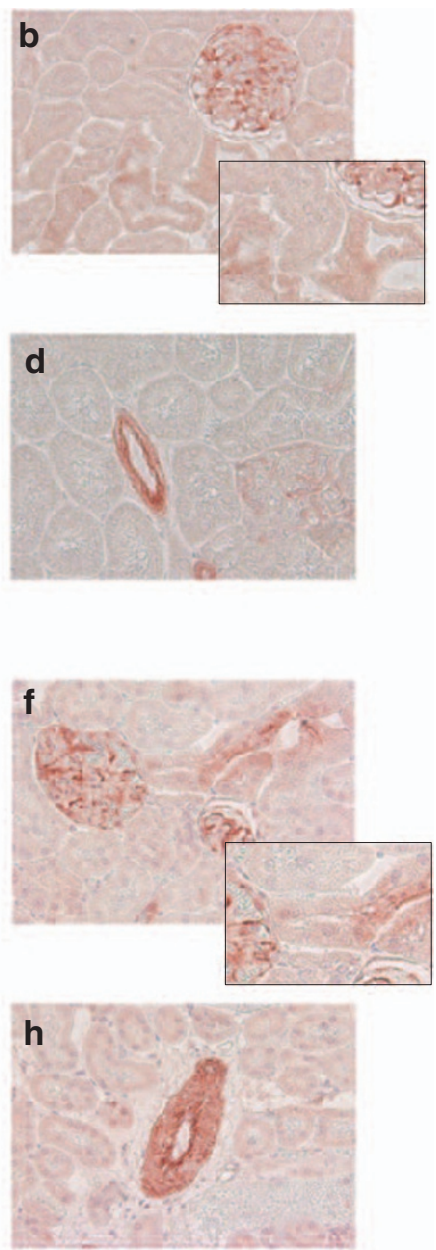

SD
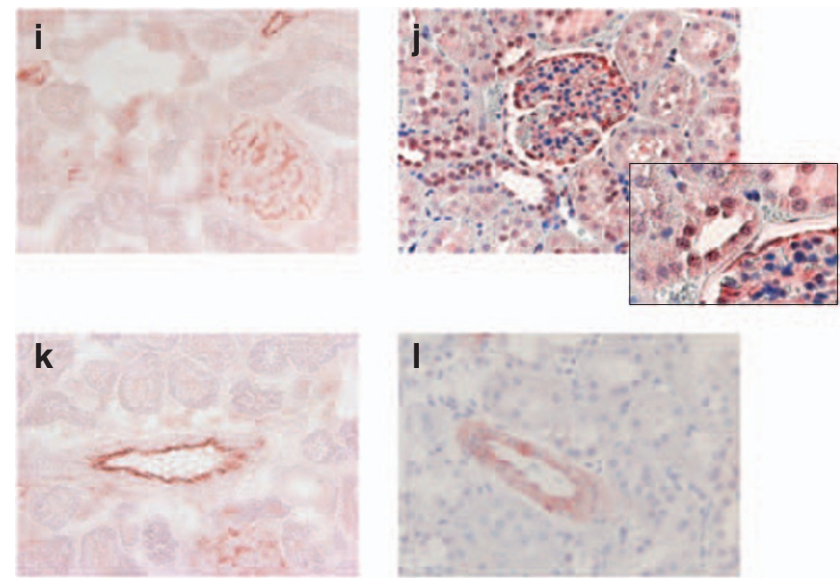

\section{TGR(mREN2)2}
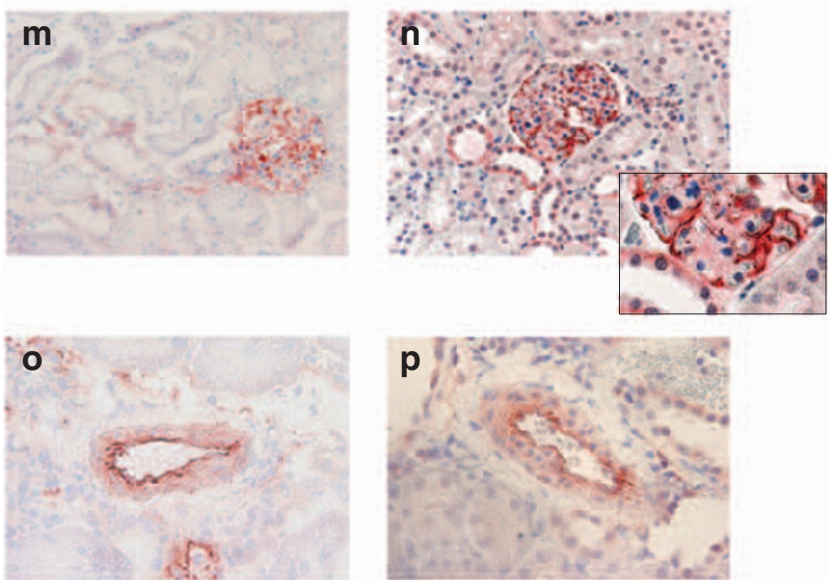

\section{CONTROLS}

\section{ACE2 peptide}

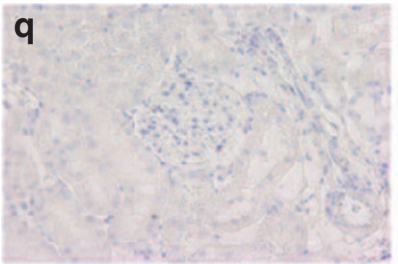

Anti NT

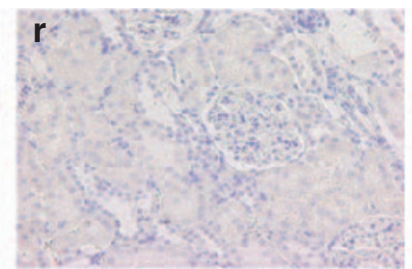

PBS

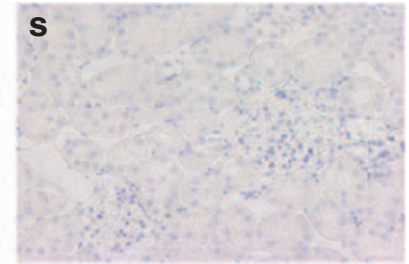

Figure 2 Immunohistochemical staining pattern of renal angiotensin-converting enzyme 2 (ACE2) of Wistar-Kyoto (WKY; a-d), stroke-prone spontaneously hypertensive (SHRSP; $\mathbf{e}-\mathbf{h})$, Spraque-Dawley (SD; $\mathbf{i}-\mathbf{l})$ and TGR(mREN2)27 (m-p) rats on frozen (left panel) and paraffin (right panel) sections and control sections (q-s). Comparable renal ACE2 expression was found in all four rat strains. In glomeruli, abundant ACE2 expression was present in visceral epithelial cells with moderate expression observed in parietal epithelial cells, whereas the glomerular mesangial and endothelial cells were consistently negative for ACE2. Overall weak ACE2 expression was present in the distal tubuli, as observed on the high magnification fields. Consistent vascular ACE2 expression was observed in vascular smooth muscle cells and endothelial cells. Control sections were incubated with anti-ACE2 antibody solution in the presence of the synthetic ACE2 peptide (q), an unrelated rabbit polyclonal antibody anti-Nitrotyrosine (anti-NT) ( $\mathbf{r}$ ) or with phosphate-buffered saline (PBS) in the absence of the primary antibody (s). These control sections did not reveal any staining.

adult SHRSP, a model of polygenetic hypertension and its normotensive reference strain, the WKY rat. Similarly, in a completely different model of monogenetic, renin-dependent hypertension, equal levels of kidney ACE2 mRNA, ACE2 protein and ACE2 activity were found in adult hypertensive homozygous TGR(mREN2)27 animals and their normotensive reference strain, a transgenic negative $\mathrm{SD}$ rat.
The hypothesis that linked ACE2 with blood pressure regulation was initially supported by a study that analyzed renal ACE2 in genetic adult hypertension in rat models. ${ }^{5}$ These findings would be theoretically in line with the hypothesis that in conditions with decreased ACE2 activity, blood pressure rises due to a prevailing AngII vasoconstrictor effect. 
Table 2 Renal ACE2 protein expression

\begin{tabular}{|c|c|c|c|c|}
\hline & $\begin{array}{l}W K Y \\
(\mathrm{n}=9)\end{array}$ & $\begin{array}{l}\text { SHRSP } \\
(\mathrm{n}=8)\end{array}$ & $\begin{array}{c}S D \\
(\mathrm{n}=6)\end{array}$ & $\begin{array}{c}\text { TGR(mREN2)27 } \\
(\mathrm{n}=6)\end{array}$ \\
\hline \multicolumn{5}{|l|}{ Glomeruli } \\
\hline Parietal epithelium & + & + & + & + \\
\hline Visceral epithelium & ++ & ++ & ++ & ++ \\
\hline Endothelium & - & - & - & - \\
\hline Mesangial cells & - & - & - & - \\
\hline \multicolumn{5}{|l|}{ Large arteries } \\
\hline VSMCs & + & + & $+/-$ & $+/-$ \\
\hline Endothelium & ++ & ++ & ++ & ++ \\
\hline \multicolumn{5}{|l|}{ Preglomerular arterioles } \\
\hline VSMCs & ++ & ++ & $+1-$ & $+/-$ \\
\hline Endothelium & ++ & ++ & ++ & ++ \\
\hline \multicolumn{5}{|l|}{ Tubuli } \\
\hline Proximal & - & - & - & - \\
\hline Distal & $+1-$ & $+1-$ & + & + \\
\hline Collecting ducts & - & - & - & - \\
\hline Peritubular capilliaries & - & - & - & - \\
\hline Vasa recta & ++ & ++ & ++ & ++ \\
\hline
\end{tabular}

Abbreviations: ACE2, angiotensin-converting enzyme 2; SD, Spraque-Dawley; SHRSP, strokeprone spontaneously hypertensive; VSMC, vascular smooth muscle cell; WKY, Wistar-Kyoto. Immunohistochemical staining pattern of renal ACE2 in hypertensive rat strains and their normotensive reference strain. The combined intensity and distribution of ACE2 immunostaining were determined on a scale of 0 to $2+(-$, absent; + /-, very weak staining; + , moderate staining; ++ , strong staining).

Table 3 Renal ACE2 activity

ACE2 activity $\mathrm{mmol}$ Mca-AP-OH/mg protein/h

\begin{tabular}{lrl}
\cline { 2 - 3 } Rat strain & Mean & SD \\
\hline WKY $(n=9)$ & 3.46 & 0.37 \\
$\operatorname{SHRSP}(n=8)$ & 3.38 & 0.32 \\
$\operatorname{SD}(n=6)$ & 10.97 & 2.63 \\
$\operatorname{TGR}(\operatorname{mREN} 2) 27(n=6)$ & 11.08 & 3.66
\end{tabular}

Abbreviations: ACE2, angiotensin-converting enzyme 2; SD, Spraque-Dawley; SHRSP, strokeprone spontaneously hypertensive; WKY, Wistar-Kyoto.

The amount of Mca-AP generated from Mca-APK(Dnp) by $1 \mathrm{mg}$ of protein from kidney tissues of rat within $1 \mathrm{~h}$.

Recent studies have re-examined the role of renal ACE2 in blood pressure regulation with varying conclusions. ${ }^{10,15,16}$ In experimental studies, first, in knockout mice lacking the ACE2 gene, blood pressure is either normal or only mildly increased compared with control littermates. ${ }^{5,9,17}$ In rats, Pendergrass et al. ${ }^{18}$ found that hypertensive male mRen2.Lewis rats had lower cortical ACE2 activity than normotensive Lewis rats, but no difference in ACE2 activity was present between female hypertensive and normotensive rats in the same study. Paradoxically, male mRen2.Lewis had a higher blood pressure than females despite significantly higher renal ACE2 activity. Thus, the association between lower renal ACE2 levels and higher blood pressure that was observed in the early studies is apparently not a uniform phenomenon, and seems to be context dependent, as shown by the effect of gender in the Pendergast study.

Human renal biopsy data illustrate the complexity of the possible associations between renal ACE2 and blood pressure. Wakahara et al. ${ }^{19}$ showed that renal ACE2 is expressed synergistically with ACE, supporting pathophysiological relevance of the combination of the two, rather than for ACE2 alone. Moreover, they found that blood pressure was an independent confounding factor for renal ACE/ACE2 ratio, at expression as well as at protein level, in patients with hypertension secondary due to diverse renal conditions. These data support the presence of an association between renal ACE/ACE2 balance and hypertension in renal patients, with a higher ACE/ACE2 ratio being associated with hypertension. These association data in renal patients, however, do not allow to dissect between hypertension as a cause or consequence of elevated blood pressure, or to conclude upon a role of ACE2 in essential hypertension, in the absence of renal disease.

Epidemiological data so far have not provided support for a role of ACE2 in hypertension. Neither in candidate gene studies ${ }^{10}$ nor in two recent genome-wide association studies ${ }^{20,21}$ was the ACE2 locus associated with blood pressure or hypertension.

The intrarenal localization of ACE2 could potentially provide clues as to its functional role. However, data on the intrarenal localization of ACE2 are not consistent. Our current findings in rat renal tissue are somewhat at variance with earlier reports that provided varying results. In the current study we found predominant glomerular and endothelial ACE2 staining with weak staining in distal and negative staining in proximal tubuli. Others, however, have reported ACE2positive proximal tubuli and/or ACE2-negative glomeruli in male SD rats using commercially available goat polyclonal anti-ACE2 antibodies $^{22}$ and in female SD rats with self-prepared mouse monoclonal and rabbit polyclonal anti-ACE2 antibodies. ${ }^{23,24}$ These reports strongly emphasize the lack of ACE2 protein in glomeruli. On the other hand, with the above mentioned commercially available goat polyclonal anti-ACE2 antibody, ACE2-positive staining was subsequently reported to be present not only in tubular segments, but also in glomeruli and endothelial cells of male adult SD rats. ${ }^{25}$ Similarly, in adult SHR and WKY rats, ACE2 mRNA and protein was present in proximal tubuli and large vessels with weak distal tubular and glomerular presence using the initial rabbit polyclonal anti-ACE2. ${ }^{26}$ Considering these between-laboratory discrepancies, in the current study we took great care to rigorously test validity and reproducibility of our immunohistochemistry data. To this purpose we tested different antibodies, and moreover, we reproduced the findings on paraffin as well as frozen sections. The similarity of our findings on renal ACE2 in paraffin and frozen sections, as well as the reproducibility of it for two different hypertensive and normotensive strains, supports the robustness of our findings. Hence, although our findings are internally consistent, for the moment between-laboratory differences are still difficult to interpret and hamper a consistent overall conclusion on the intrarenal localization of ACE2.

It should be noted that there are species differences in the renal localization of ACE2. ACE2 expression pattern in human kidneys is similar to the one in mouse kidneys, ${ }^{1,22,27}$ with primary localization in the proximal tubular epithelium. However, inconsistencies can be found in mouse glomerular ACE2 presence as described even by the same group. ${ }^{28,29}$ Besides, kinetic differences in AngI and AngII metabolism are shown to be exist between rat, human and sheep kidneys. ${ }^{25,30,31}$

There are some limitations to our study. First, our data were obtained in adult animals with established hypertension and hence do not rule out a role for renal ACE2 in the early onset of hypertension. Second, because of technical issues, we only can provide data on ACE2 whereas the relevant pathogenetic entity might well be ACE/ ACE2 ratio. Taking these limitations in mind, our data do not support a role for renal ACE2 in established hypertension in genetically determined hypertension in rats. Yet, our data do not completely 
rule out a possible contribution to specific hypertensive conditions such as Sabra rat model, or an important (protective) role for tissue ACE2 at local organ-specific sites. ${ }^{28,32-35}$

In conclusion, kidney ACE2 expression and activity is similar in polygenetic and monogenetic adult rat models of hypertension as compared with their normotensive reference strains. The precise role of renal ACE2 in hypertension remains to be established.

\section{CONFLICT OF INTEREST}

The authors declare no conflict of interest.

\section{ACKNOWLEDGEMENTS}

We thank Barry Jutten for technical assistance. This study was supported by University Medical Center Groningen, Graduate School for Drug Exploration (GUIDE), and grants from the BMBF, Grant KGCV1, 01 GS0416 in NGFN2 and the DFG Grant GRK 865 'Vaskuläre Regulationsmechanismen'.

1 Hamming I, Cooper ME, Haagmans BL, Hooper NM, Korstanje R, Osterhaus AD, Timens W, Turner AJ, Navis G, van Goor H. The emerging role of ACE2 in physiology and disease. J Pathol 2007; 212: 1-11.

2 Tipnis SR, Hooper NM, Hyde R, Karran E, Christie G, Turner AJ. A human homolog of angiotensin-converting enzyme. Cloning and functional expression as a captoprilinsensitive carboxypeptidase. J Biol Chem 2000; 275: 33238-33243.

3 Vickers C, Hales P, Kaushik V, Dick L, Gavin J, Tang J, Godbout K, Parsons T, Baronas E, Hsieh F, Acton S, Patane M, Nichols A, Tummino P. Hydrolysis of biological peptides by human angiotensin-converting enzyme-related carboxypeptidase. J Biol Chem 2002; 277: $14838-14843$

4 Yagil Y, Yagil C. Hypothesis: ACE2 modulates blood pressure in the mammalian organism. Hypertension 2003; 41: 871-873.

5 Crackower MA, Sarao R, Oudit GY, Yagil C, Kozieradzki I, Scanga SE, Oliveira-dosSantos AJ, da Costa J, Zhang L, Pei Y, Scholey J, Ferrario CM, Manoukian AS, Chappell $\mathrm{MC}$, BackX PH, Yagil Y, Penninger JM. Angiotensin-converting enzyme 2 is an essential regulator of heart function. Nature 2002; 417: 822-828.

6 Hilbert P, Lindpaintner K, Beckmann JS, Serikawa T, Soubrier F, Dubay C, Cartwright P, De Gouyon B, Julier C, Takahasi S. Chromosomal mapping of two genetic loci associated with blood-pressure regulation in hereditary hypertensive rats. Nature 1991; 353: 521-529.

7 Yagil C, Sapojnikov M, Kreutz R, Zurcher H, Ganten D, Yagil Y. Role of chromosome X in the Sabra rat model of salt-sensitive hypertension. Hypertension 1999; 33: 261-265.

8 Zhong JC, Huang DY, Yang YM, Li YF, Liu GF, Song XH, Du K. Upregulation of angiotensin-converting enzyme 2 by all-trans retinoic acid in spontaneously hypertensive rats. Hypertension 2004; 44: 907-912.

9 Gurley SB, Allred A, Le TH, Griffiths R, Mao L, Philip N, Haystead TA, Donoghue M, Breitbart RE, Acton SL, Rockman HA, Coffman TM. Altered blood pressure responses and normal cardiac phenotype in ACE2-null mice. J Clin Invest 2006; 116: 2218-2225.

10 Benjafield AV, Wang WY, Morris BJ. No association of angiotensin-converting enzyme 2 gene (ACE2) polymorphisms with essential hypertension. Am J Hypertens 2004; 17: 624-628.

11 Bolbrinker J, Markovic S, Wehland M, Melenhorst WB, van Goor H, Kreutz R. Expression and response to angiotensin-converting enzyme inhibition of matrix metalloproteinases 2 and 9 in renal glomerular damage in young transgenic rats with renindependent hypertension. J Pharmacol Exp Ther 2006; 316: 8-16.

12 Kreutz R, Kovacevic L, Schulz A, Rothermund L, Ketteler M, Paul M. Effect of high $\mathrm{NaCl}$ diet on spontaneous hypertension in a genetic rat model with reduced nephron number. J Hypertens 2000; 18: 777-782.

13 Donoghue M, Hsieh F, Baronas E, Godbout K, Gosselin M, Stagliano N, Donovan M, Woolf $B$, Robison K, Jeyaseelan R, Breitbart RE, Acton S. A novel angiotensinconverting enzyme-related carboxypeptidase (ACE2) converts angiotensin I to angiotensin 1-9. Circ Res 2000; 87: E1-E9.

14 Huang L, Sexton DJ, Skogerson K, Devlin M, Smith R, Sanyal I, Parry T, Kent R, Enright J, Wu QL, Conley G, DeOliveira D, Morganelli L, Ducar M, Wescott CR, Ladner RC. Novel peptide inhibitors of angiotensin-converting enzyme 2. J Biol Chem 2003; 278: $15532-15540$.

15 Huentelman MJ, Grobe JL, Vazquez J, Stewart JM, Mecca AP, Katovich MJ, Ferrario CM, Raizada MK. Protection from angiotensin II-induced cardiac hypertrophy and fibrosis by systemic lentiviral delivery of ACE2 in rats. Exp Physiol 2005; 90: 783-790.

16 Riviere G, Michaud A, Breton C, VanCamp G, Laborie C, Enache M, Lesage J, Deloof S, Corvol P, Vieau D. Angiotensin-converting enzyme 2 (ACE2) and ACE activities display tissue-specific sensitivity to undernutrition-programmed hypertension in the adult rat. Hypertension 2005; 46: 1169-1174.

17 Gurley SB, Coffman TM. Angiotensin-converting enzyme 2 gene targeting studies in mice: mixed messages. Exp Physiol 2008; 93: 538-542.
18 Pendergrass KD, Pirro NT, Westwood BM, Ferrario CM, Brosnihan KB, Chappell MC. Sex differences in circulating and renal angiotensins of hypertensive mRen(2). Lewis but not normotensive Lewis rats. Am J Physiol Heart Circ Physiol 2008; 295: $\mathrm{H} 10-\mathrm{H} 20$.

19 Wakahara S, Konoshita T, Mizuno S, Motomura M, Aoyama C, Makino Y, Kato N, Koni I, Miyamori I. Synergistic expression of angiotensin-converting enzyme (ACE) and ACE2 in human renal tissue and confounding effects of hypertension on the ACE to ACE2 ratio. Endocrinology 2007; 148: 2453-2457.

20 Levy D, Ehret GB, Rice K, Verwoert GC, Launer LJ, Dehghan A, Glazer NL, Morrison AC, Johnson AD, Aspelund T, Aulchenko Y, Lumley T, Kottgen A, Vasan RS, Rivadeneira F, Eiriksdottir G, Guo X, Arking DE, Mitchell GF, Mattace-Raso FU, Smith AV, Taylor K, Scharpf RB, Hwang SJ, Sijbrands EJ, Bis J, Harris TB, Ganesh SK, O’Donnell CJ, Hofman A, Rotter JI, Coresh J, Benjamin EJ, Uitterlinden AG, Heiss G, Fox CS, Witteman JC, Boerwinkle E, Wang TJ, Gudnason V, Larson MG, Chakravarti A, Psaty $\mathrm{BM}$, van Duijn CM. Genome-wide association study of blood pressure and hypertension. Nat Genet 2009; 41: 677-687.

21 Newton-Cheh C, Johnson T, Gateva V, Tobin MD, Bochud M, Coin L, Najiar SS, Zhao JH, Heath SC, Eyheramendy S, Papadakis K, Voight BF, Scott LJ, Zhang F, Farrall M, Tanaka T, Wallace C, Chambers JC, Khaw KT, Nilsson P, van der Harst P, Polidoro S, Grobbee DE, Onland-Moret NC, Bots ML, Wain LV, Elliott KS, Teumer A, Luan J, Lucas G, Kuusisto J, Burton PR, Hadley D, McArdle WL, Brown M, Dominiczak A, Newhouse SJ, Samani NJ, Webster J, Zeggini E, Beckmann JS, Bergmann S, Lim N, Song K, Vollenweider P, Waeber G, Waterworth DM, Yuan X, Groop L, Orho-Melander M, Allione A, Di Gregorio A, Guarrera S, Panico S, Ricceri F, Romanazzi V, Sacerdote C, Vineis P, Barroso I, Sandhu MS, Luben RN, Crawford GJ, Jousilahti P, Perola M, Boehnke M, Bonnycastle LL, Collins FS, Jackson AU, Mohlke KL, Stringham HM, Valle TT, Willer CJ, Bergman RN, Morken MA, Doring A, Gieger C, Illig T, Meitinger T, Org E, Pfeufer A, Wichmann HE, Kathiresan S, Marrugat J, O'Donnell CJ, Schwartz SM, Siscovick DS, Subirana I, Freimer NB, Hartikainen AL, McCarthy MI, O'Reilly PF, Peltonen L, Pouta A, de Jong PE, Snieder H, van Gilst WH, Clarke R, Goel A, Hamsten A, Peden JF, Seedorf U, Syvanen AC, Tognoni G, Lakatta EG, Sanna S, Scheet P, Schlessinger D, Scuteri A, Dorr M, Ernst F, Felix SB, Homuth G, Lorbeer R, Reffelmann T, Rettig R, Volker U, Galan P, Gut IG, Hercberg S, Lathrop GM, Zelenika D, Deloukas P, Soranzo N, Williams FM, Zhai G, Salomaa V, Laakso M, Elosua R, Forouhi NG, Volzke H, Uiterwaal CS, van der Schouw YT, Numans ME, Matullo G, Navis G, Berglund G, Bingham SA, Kooner JS, Connell JM, Bandinelli S, Ferrucci L, Watkins H, Spector TD, Tuomilehto J, Altshuler D, Strachan DP, Laan M, Meneton P, Wareham NJ, Uda M, Jarvelin MR, Mooser V, Melander O, Loos RJ, Elliott P, Abecasis GR, Caulfield M, Munroe PB. Genome-wide association study identifies eight loci associated with blood pressure. Nat Genet 2009; 41: 666-676.

22 Gembardt F, Sterner-Kock A, Imboden H, Spalteholz M, Reibitz F, Schultheiss HP Siems WE, Walther T. Organ-specific distribution of ACE2 mRNA and correlating peptidase activity in rodents. Peptides 2005; 26: 1270-1277.

23 Brosnihan KB, Neves LA, Joyner J, Averill DB, Chappell MC, Sarao R, Penninger J, Ferrario CM. Enhanced renal immunocytochemical expression of ANG-(1-7) and ACE2 during pregnancy. Hypertension 2003; 42: 749-753.

24 Joyner J, Neves LA, Granger JP, Alexander BT, Merrill DC, Chappell MC, Ferrario CM, Davis WP, Brosnihan KB. Temporal-spatial expression of ANG-(1-7) and angiotensinconverting enzyme 2 in the kidney of normal and hypertensive pregnant rats. $A m ~ J$ Physiol Regul Integr Comp Physiol 2007; 293: R169-R177.

25 Li N, Zimpelmann J, Cheng K, Wilkins JA, Burns KD. The role of angiotensin converting enzyme 2 in the generation of angiotensin 1-7 by rat proximal tubules. Am J Physiol Renal Physiol 2005; 288: F353-F362.

26 Tikellis C, Cooper ME, Bialkowski K, Johnston Cl, Burns WC, Lew RA, Smith Al, Thomas MC. Developmental expression of ACE2 in the SHR kidney: a role in hypertension? Kidney Int 2006; 70: 34-41.

27 Hamming I, Timens W, Bulthuis ML, Lely AT, Navis GJ, van Goor H. Tissue distribution of ACE2 protein, the functional receptor for SARS coronavirus. A first step in understanding SARS pathogenesis. J Pathol 2004; 203: 631-637.

28 Ye M, Wysocki J, Naaz P, Salabat MR, LaPointe MS, Batlle D. Increased ACE 2 and decreased ACE protein in renal tubules from diabetic mice: a renoprotective combination? Hypertension 2004; 43: 1120-1125.

29 Ye M, Wysocki J, William J, Soler MJ, Cokic I, Batlle D. Glomerular localization and expression of angiotensin-converting enzyme 2 and angiotensin-converting enzyme: implications for albuminuria in diabetes. J Am Soc Nephrol 2006; 17: 3067-3075.

30 Rice GI, Thomas DA, Grant PJ, Turner AJ, Hooper NM. Evaluation of angiotensinconverting enzyme (ACE), its homologue ACE2 and neprilysin in angiotensin peptide metabolism. Biochem J 2004; 383: 45-51.

31 Shaltout HA, Westwood BM, Averill DB, Ferrario CM, Figueroa JP, Diz DI, Rose JC, Chappell MC. Angiotensin metabolism in renal proximal tubules, urine, and serum of sheep: evidence for ACE2-dependent processing of angiotensin II. Am J Physiol Renal Physiol 2007; 292: F82-F91.

32 Lely AT, Hamming I, van Goor H, Navis GJ. Renal ACE2 expression in human kidney disease. J Pathol 2004; 204: 587-593.

33 Burchill L, Velkoska E, Dean RG, Lew RA, Smith Al, Levidiotis V, Burrell LM. Acute kidney injury in the rat causes cardiac remodelling and increases angiotensin-converting enzyme 2 expression. Exp Physiol 2008; 93: 622-630.

34 Burrell LM, Risvanis J, Kubota E, Dean RG, MacDonald PS, Lu S, Tikellis C, Grant SL, Lew RA, Smith AI, Cooper ME, Johnston Cl. Myocardial infarction increases ACE2 expression in rat and humans. Eur Heart J 2005; 26: 369-375.

35 Goulter AB, Goddard MJ, Allen JC, Clark KL. ACE2 gene expression is up-regulated in the human failing heart. BMC Med 2004; 2: 19. 